\title{
Article
}

\section{Quantification of toxic hazard from fires in buildings}

\author{
Hull, T Richard, Brein, Dieter and Stec, Anna A \\ Available at http://clok.uclan.ac.uk/16621/
}

Hull, T Richard ORCID: 0000-0002-7970-4208, Brein, Dieter and Stec, Anna A ORCID: 0000-0002-6861-0468 (2016) Quantification of toxic hazard from fires in buildings. Journal of Building Engineering, 8 . pp. 313-318.

It is advisable to refer to the publisher's version if you intend to cite from the work. http://dx.doi.org/10.1016/j.jobe.2016.02.014

For more information about UCLan's research in this area go to

http://www.uclan.ac.uk/researchgroups/ and search for < name of research Group $>$.

For information about Research generally at UCLan please go to http://www.uclan.ac.uk/research/

All outputs in CLoK are protected by Intellectual Property Rights law, including Copyright law. Copyright, IPR and Moral Rights for the works on this site are retained by the individual authors and/or other copyright owners. Terms and conditions for use of this material are defined in the policies page.

\section{CLoK}

Central Lancashire online Knowledge www.clok.uclan.ac.uk

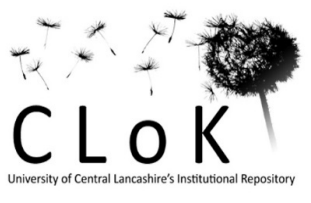




\title{
Quantification of Toxic Hazard from Fires in Buildings
}

\author{
T Richard Hull*1, Dieter Brein² and Anna A Stec ${ }^{1}$
}

1. Centre for Fire and Hazards Science, University of Central Lancashire, Preston, PR1 2HE, UK

2. Research Centre for Fire Protection Technology, Karlsruhe Institute of Technology, 76187 Karlsruhe, Germany

\section{ABSTRACT}

Fire safe design requires a builder, architect or fire safety engineer to ensure that the available safe escape time (ASET) exceeds the required safe escape time (RSET), for which an estimate of toxic hazard from smoke is required. In Europe, the burning behaviour of construction products must be tested and labelled according to their Euroclass, based on their fire performance in a range of tests. Each Euroclass can be used to indicate a mass loss range. The yields of toxic products may be determined for each material as a function of fire condition. Reliable data has been widely reported from the steady state tube furnace (ISO TS 19700) and the fire propagation apparatus (ISO 12136) for both well-ventilated and under-ventilated flaming. By combining the toxic product yields, most easily expressed as an $\mathrm{LC}_{50}$, with the mass loss range, a methodology is proposed for quantifying the volume of toxic effluent produced by burning construction materials within an enclosure. This allows a maximum safe loading of construction materials to be quantified for a given volume of enclosure. This is intended to ensure that estimates of toxic hazard are undertaken as part of any fire hazard assessment, not to replace more rigorous engineering analyses. It will allow architects and builders to ensure that their materials' selection does not compromise fire safety.

Keywords: Fire, Toxicity, ASET, Euroclass, construction, SBI, ISO 19700.

\footnotetext{
*Corresponding author trhull@uclan.ac.uk
} 


\section{NOMENCLATURE}

$\left[\mathrm{CO}_{2}\right] \quad$ Carbon dioxide concentration (\% by volume)

$\left[\mathrm{O}_{2}\right] \quad$ Oxygen concentration (\% by volume)

Concentration of toxicant $X$

[X] (expressed in same units as $\mathrm{LC}_{50}, \mathrm{x}$ e.g. $\mu \mathrm{L} \mathrm{L}^{-1}$ )

A Acidosis factor (in FED equation)

$b^{\prime \prime} \quad$ Fractional burn area

$\Delta \mathrm{H}_{\mathrm{c}} \quad$ Heat of combustion (MJ kg-1)

FED Fractional Effective Dose

Lethal concentration of toxicant $X$ to $50 \%$ of the exposed population

$\mathrm{LC}_{50, \mathrm{X}} \quad$ (expressed in same units as [X] e.g. $\mu \mathrm{L} \mathrm{L}^{-1}$ )

$\mathrm{L}_{\mathrm{s} \text {, ha }} \quad$ Maximum safe loading, for a healthy adult population $\left(\mathrm{m}^{2}\right.$ per $\left.100 \mathrm{~m}^{-3}\right)$

$\mathrm{m} \quad$ Mass of material $(\mathrm{kg})$

$m_{E}^{\prime \prime} \quad$ Mass of material exposed, per unit area $\left(\mathrm{kg} \mathrm{m}^{-2}\right)$

$m_{L} \quad$ Mass of material lost $(\mathrm{kg})$

$m_{L} " \quad$ Mass of material lost, per unit area $\left(\mathrm{kg} \mathrm{m}^{-2}\right)$

Material-LC $\mathrm{C}_{50}$ - the mass of material required to generate a toxic

$\mathrm{m}-\mathrm{LC}_{50} \quad$ atmosphere on burning, lethal to $50 \%$ of the population $\left(\mathrm{g} \mathrm{m}^{-3}\right)$

$\rho^{\prime \prime} \quad$ Material density per unit area $\left(\mathrm{kg} \mathrm{m}^{-2}\right)$

$t_{b} \quad$ Fractional burn thickness

THR Total heat release (kJ)

$\mathrm{THR}_{600} \quad$ Total heat release in first $600 \mathrm{~s}$ of SBI test $(\mathrm{kJ})$

$\checkmark \quad$ Volume of enclosure containing fire effluent $\left(\mathrm{m}^{3}\right)$

$\mathrm{V}_{\mathrm{CO}_{2}} \quad$ Hyperventilation Correction Factor

$\mathrm{V}_{\mathrm{LC}_{50}} \quad$ Lethal volume (of toxic fire effluent) $\left(\mathrm{m}^{3}\right)$

$Y_{v} \quad$ Volatile fraction 


\section{INTRODUCTION}

Fire effluent toxicity is responsible for the majority of deaths, and the majority of injuries, from unwanted fires [1]. Fire safety engineers have been very successful in minimising structural failure in building fires, but no simple methodology exists to estimate the toxic hazard from burning building materials and/or contents. The toxic hazard is the potential for harm resulting from exposure to toxic combustion products [2]. The toxic hazard depends on two major parameters: the mass loss rate of the burning object; and the toxicity of the fire effluent it produces per unit mass of fuel, which is itself a function of both the material composition and the fire condition. Only with an estimate of toxic hazard will a builder, architect or fire safety engineer be able to ensure the fire safety of a building, by being able to demonstrate that the available safe escape time (ASET) exceeds the required safe escape time (RSET)[3].

In Europe, the Construction Products Regulations [4] require the fire performance of construction products to be tested and labelled according to their Euroclass (e.g. A1 is non-combustible; D is typical for untreated timber; $F$ is untested etc.). This assesses fire performance in terms of established parameters such as fire growth rate (FIGRA), heat release rate (HRR) and smoke growth rate (SMOGRA). Surprisingly, fire toxicity is not part of the Euroclass system. The Euroclasses are based on performance in a room scale reference scenario, in this case the ISO 9705 room [5]. To save testing such large quantities of each product, intermediate scale tests have been developed, which are supposed to replicate behavior in the reference scenario. Thus, the allocation of most Euroclasses is based on performance in the single burning item (SBI) test, EN 13823 [6]. This paper describes a methodology for using the Euroclass to estimate the mass loss. In the assessment of flammability, such as in the Euroclass system, the worst case scenario is the normal atmospheric oxygen concentration, $21 \%$ oxygen (by volume). In the assessment of fire toxicity, the yields of most toxicants increase by a factor of around 20 when the oxygen concentration falls to $15 \%$ (by volume) [7].

The toxic product yields may be determined for each material as a function of fire condition. Reliable data has been widely reported from the steady state tube furnace (ISO TS 19700) [8] and the fire propagation apparatus (ISO 12136) [9] for both well-ventilated and under-ventilated flaming; it has been reported from the cone calorimeter (ISO 5660) with a non-standard controlled 
atmosphere enclosure, but only appears to replicate the least toxic, well-ventilated flaming condition [10]. By combining the toxicity data, most easily expressed as a material- $\mathrm{LC}_{50}$ (the mass of material required to produce a lethal fire effluent of volume $1 \mathrm{~m}^{3}$ ), for a particular fire condition, with the mass loss over a fixed time (10 minutes in the current work), a methodology is proposed for quantifying the volume of toxic effluent produced by burning construction materials within an enclosure. This allows a maximum safe loading of construction materials to be quantified for a given volume of enclosure. This is intended to ensure that estimates of toxic hazard are undertaken as part of any fire hazard assessment, not to replace more rigorous engineering analyses. It will allow architects and builders to ensure that their materials' selection does not compromise fire safety.

National building codes stipulate the levels of safety for different types of building and use. They will normally specify a minimum Euroclass for a particular application. The focus of these government regulations and guidance is the hazard to life from fire. In addition, insurers often specify the materials of construction for particular industrial buildings in order to protect their risk from property loss, for which fire toxicity is a lesser concern. In the UK, Approved Document B provides guidance for building specifiers to select appropriate construction materials using their Euroclass, for the level of hazard associated with the particular type of construction (e.g. multistorey, multi occupancy dwelling, school, hospital etc.). As an alternative to following the guidance in Approved Document B, a performance-based approach may be adopted using techniques of fire safety engineering to ensure the fire safety of building occupants. On completion of the construction, the Regulatory Reform (Fire Safety) Order (2005) puts the onus on building occupiers to ensure the fire safety of the buildings in their control. This means that individuals with no formal expertise in fire safety are responsible for ensuring the ongoing fire safety of buildings. Thus simple tools, like the approach described here, are essential for them to ensure the safety of the people using their buildings. 


\section{ESTIMATION OF FIRE TOXICITY}

Toxic fire hazard may be predicted by using two parameters:

- The toxic product yields (a function of material and fire condition [11]).

- The mass loss of fuel (a function of flammability, fire conditions and time).

The burning of an organic material, such as a polymer, produces a cocktail of products. These range from the relatively harmless fully-oxidised products, such as carbon dioxide $\left(\mathrm{CO}_{2}\right)$ and water, to products of incomplete combustion, including carbon monoxide (CO), hydrogen cyanide (HCN), organoirritants etc. Significant differences in toxic product yields arise between flaming and nonflaming combustion, and between well-ventilated and under-ventilated flaming.

In addition to water, $\mathrm{CO}_{2}, \mathrm{CO}$, and $\mathrm{HCN}$, fire gases contain a mixture of partially oxidised products, such as aldehydes; fuel or fuel degradation products, such as aliphatic or aromatic hydrocarbons; and other stable gas molecules, such as nitrogen, nitrogen oxides and hydrogen halides. $\mathrm{CO}$ is one of the most toxicologically significant components in fire gases, preventing oxygen transport by the formation of carboxyhaemoglobin, and acting as a marker for other toxic products of incomplete combustion, such as HCN and oxygenated organics. HCN is important because it is over 20 times more toxic than $\mathrm{CO}$, preventing uptake of oxygen by the body's cells. The combined effect of these toxicants has been expressed as a fractional effective dose (FED) using Purser's model (Equation 1) (ISO 13344). The gas- $\mathrm{LC}_{50}$ values were obtained from rat lethality experiments. In essence the ratio of the concentration of the individual toxicants to their lethal concentration is summed for each toxicant. These are multiplied by the factor $V_{\mathrm{CO}_{2}}$, because $\mathrm{CO}_{2}$ stimulates an increase in the respiration rate. In addition, an acidosis factor and an oxygen depletion factor are included in the overall summation. An FED equal to 1 would be lethal to $50 \%$ of the exposed population.

$$
\begin{aligned}
\mathrm{FED} & =\left\{\frac{[\mathrm{CO}]}{\mathrm{LC}_{50, \mathrm{CO}}}+\frac{[\mathrm{HCN}]}{\mathrm{LC}_{50, \mathrm{HCN}}}+\frac{[\mathrm{HCl}]}{\mathrm{LC}_{50, \mathrm{HCl}}}+\ldots . .\right\} \times \mathrm{V}_{\mathrm{CO}_{2}}+\mathrm{A}+\frac{21-\left[\mathrm{O}_{2}\right]}{21-5.4} \\
\mathrm{~V}_{\mathrm{CO}_{2}} & =1+\frac{\exp \left(0.14\left[\mathrm{CO}_{2}\right]\right)-1}{2}
\end{aligned}
$$

A is an acidosis factor equal to $\left[\mathrm{CO}_{2}\right] \times 0.05$.

The lethality as FED can be conveniently expressed as a material- $\mathrm{LC}_{50}$ (Equation 2 ). This is the mass of material (grams of fuel) needed to produce $1 \mathrm{~m}^{3}$ of lethal effluent (FED $=1$ ).

$$
\text { material }-\mathrm{LC}_{50}=\frac{M}{\mathrm{FED} \times V}
$$


Comparing the toxic potencies of different materials, the lower the $\mathrm{LC}_{50}$ (the smaller the amount of materials necessary to reach the toxic potency) the more toxic the material is. $\mathrm{LC}_{50}$ values should be referenced to the fire condition under which they were measured.

\section{MEASUREMENT OF TOXIC PRODUCT YIELDS}

The steady state tube furnace, ISO TS 19700 [8] has been designed to investigate the effect of material chemistry and fire conditions on the toxic product yields. This is one of the only techniques capable of replicating individual fire conditions, including the most toxic, under-ventilated combustion. The apparatus may be set up to pyrolyse material without flaming with the furnace set below the material's autoignition temperature, or to burn materials at a particular fire condition. The key fire conditions are temperature and ventilation. Flaming combustion can range from well-ventilated to under-ventilated, forcing steady state burning under the most toxic, oxygen-depleted conditions. It does so by feeding the sample and a controlled flow of air into a tube furnace at a fixed rate over about $\mathbf{2 0}$ minutes, so that the flame front is held stationary relative to the furnace. This enables it to provide reliable data on the product yields for flaming combustion as a function of equivalence ratio. Unlike a "flammability test" where a material's chemistry dictates the rate of burning, in the steady state tube furnace all combustible materials are burned at a fixed rate, independent of their flammability.

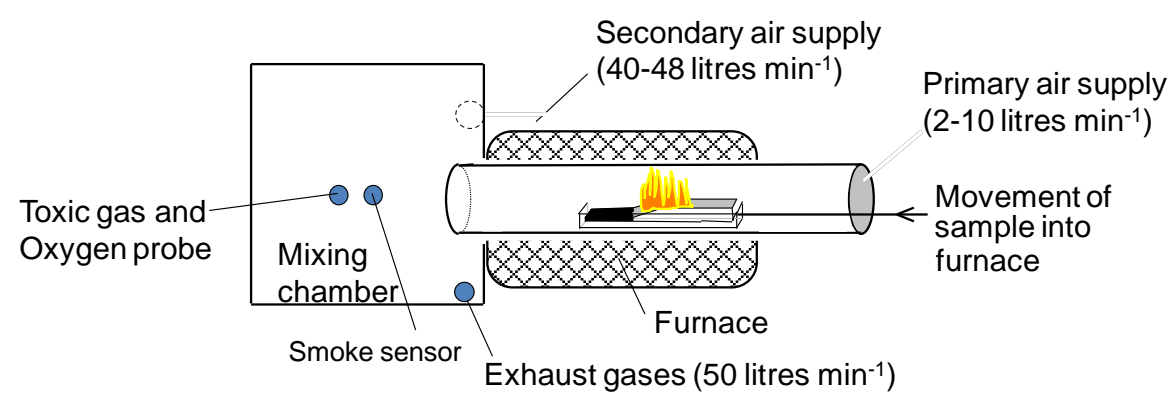

Figure 1 The steady state tube furnace apparatus (ISO TS 19700) 
The apparatus is shown in Figure 1. Samples are fed into the furnace in a quartz boat travelling around $40 \mathrm{~mm} \mathrm{~min}^{-1}$ to give a mass feed rate of approximately $1 \mathrm{~g} \mathrm{~min}^{-1}$. By varying the primary air flow rate, different fire conditions can be replicated. The combustion products are passed from the tube furnace into the mixing chamber, where they are diluted to a constant volume of $50 \mathrm{~L} \mathrm{~min}^{-1}$. Oxygen depletion and yields of toxic products may be determined for each fire condition [12, 13].

\section{ESTIMATION OF MASS LOSS OF A BURNING MATERIAL}

The mass loss of a burning material is dependent on its flammability. Various attempts have been made to identify the controlling parameters $[14,15]$. The attack of fire can be separated into the extent of penetrative burning (into the bulk of the material) and the surface spread of flame. The penetrative burning will be a function of the ratio of the heat of combustion to the heat of gasification, the radiant component of heat transfer, and for certain materials, the char yield (which will slow down the rate of burning). The surface spread of flame will depend primarily on the ignitability of the material, the radiant component of heat transfer, and the thermal properties of the surface $(\mathrm{k} \rho \mathrm{C})$. In both cases these will be highly dependent on the geometry and other scenario dependent aspects of the fire condition. For this approach to toxic fire hazard assessment, it is necessary to identify a simple method to account for the very large differences in combustibility of construction materials, in order to estimate the mass loss on burning. The most conservative assumption would be to assume that all the combustible material burnt completely. However, in a typical fire, in the first 10 minutes, during which time escape should be nearing completion, a 10 $\mathrm{cm}$ thick sheet of polystyrene foam insulation may burn completely, while a $10 \mathrm{~cm}$ thick wood panel may retain more than $90 \%$ of its mass. Thus, to make a valid comparison, a more realistic estimation of the mass loss must be obtained. The Euroclass system specifies ranges of fire performance. Thus a consistent set of data exists for all European construction products from which the mass loss may be estimated. Table 1 gives an indication of the typical materials in each Euroclass. 
Table 1 Typical performance and examples for each Euroclass [16]

\begin{tabular}{|c|c|c|c|c|}
\hline Class & Performance & Fire Scenario & $\begin{array}{l}\text { Thermal } \\
\text { attack }\end{array}$ & Examples \\
\hline A1 & $\begin{array}{l}\text { No contribution } \\
\text { to fire }\end{array}$ & $\begin{array}{l}\text { Fully developed } \\
\text { fire }\end{array}$ & $>60 \mathrm{~kW} \mathrm{~m}^{-2}$ & $\begin{array}{l}\text { Non-combustible materials such as } \\
\text { stone, concrete, brick, glass or metal }\end{array}$ \\
\hline A2 & $\begin{array}{l}\text { No contribution } \\
\text { to fire }\end{array}$ & $\begin{array}{l}\text { Fully developed } \\
\text { fire }\end{array}$ & $>60 \mathrm{~kW} \mathrm{~m}^{-2}$ & $\begin{array}{l}\text { Non-combustible materials containing } \\
\text { small amounts of organic compounds, } \\
\text { such as stone wool, glass wool, } \\
\text { unpainted gypsum board }\end{array}$ \\
\hline B & $\begin{array}{l}\text { Very limited } \\
\text { contribution to } \\
\text { fire }\end{array}$ & $\begin{array}{l}\text { Single burning } \\
\text { item in room }\end{array}$ & $\begin{array}{l}>40 \mathrm{~kW} \mathrm{~m}^{-2} \\
\text { on limited } \\
\text { area }\end{array}$ & $\begin{array}{l}\text { Painted gypsum board; fire retardant } \\
\text { wood products }\end{array}$ \\
\hline $\mathrm{C}$ & $\begin{array}{l}\text { Limited } \\
\text { contribution to } \\
\text { fire }\end{array}$ & $\begin{array}{l}\text { Single burning } \\
\text { item in room }\end{array}$ & $\begin{array}{l}>40 \mathrm{~kW} \mathrm{~m}^{-2} \\
\text { on limited } \\
\text { area }\end{array}$ & $\begin{array}{l}\text { Phenolic foam, gypsum boards with thin } \\
\text { surface linings }\end{array}$ \\
\hline $\mathrm{D}$ & $\begin{array}{l}\text { Acceptable } \\
\text { contribution to } \\
\text { fire }\end{array}$ & $\begin{array}{l}\text { Single burning } \\
\text { item in room }\end{array}$ & $\begin{array}{l}>40 \mathrm{~kW} \mathrm{~m}^{-2} \\
\text { on limited } \\
\text { area }\end{array}$ & $\begin{array}{l}\text { Wood products of thickness greater } \\
\text { than } 10 \mathrm{~mm}\end{array}$ \\
\hline $\mathrm{E}$ & $\begin{array}{l}\text { Acceptable } \\
\text { contribution to } \\
\text { fire }\end{array}$ & $\begin{array}{l}\text { Small flame } \\
\text { attack }\end{array}$ & $20 \mathrm{~mm}$ flame & $\begin{array}{l}\text { Low density fibreboard, plastic based } \\
\text { insulation products }\end{array}$ \\
\hline $\mathrm{F}$ & \multicolumn{3}{|c|}{$\begin{array}{l}\text { No performance requirements - product not } \\
\text { tested }\end{array}$} & Non-fire retarded polystyrene foam \\
\hline
\end{tabular}

The very different material flammability behaviour, from Euroclass $A 1$ to $E$ or $F$, means that different methods are used for classification. For Euroclass A1, the maximum gross calorific potential (PCS) (the heat of combustion, as measured in a bomb calorimeter), must be less than 2 $M J \mathrm{~kg}^{-1}$. Since the heat of combustion of a combustible organic material generally lies between 15 $-43 \mathrm{MJ} \mathrm{kg}^{-1}$ this indicates that the material has only a small ( $\left.\sim \%\right)$ combustible fraction. This is the case for some gypsum boards with the paper facing on a non-combustible interior, or mineral wool insulation comprising non-combustible fibres with volatile, combustible binders. 
For Euroclass A2, the PCS must be less than $4 \mathrm{MJ} \mathrm{kg}^{-1}$, but the product must also be tested in the single burning item (SBI) enclosure, EN 13823 [6]. This is intended to simulate a waste bin burning in the corner of the room. A corner is lined with the product under test, a triangular propane burner is located at the base of the internal corner, and a total area of $2.25 \mathrm{~m}^{2}$ is exposed on the internal face. Euroclass $B$ and $C$ must also be tested in the SBI. For Euroclass $A 2$ and $B$, the total heat release (THR 600 ) in the first 600 seconds must be less than 7.5 MJ. For Euroclass $C, T^{2} R_{600}$ must be less than 15 MJ. Thus, for Euroclasses A1, A2, B and C, the maximum mass loss in the first 10 minutes (used as an estimate of escape time, RSET) can be determined from equation 3.

$$
m_{L}=\frac{T H R_{600}}{\Delta H_{C}}
$$

For Euroclass D, only the fire growth rate index (FIGRA) is specified, not the total heat release. For Euroclass E, products only have to show limited flame spread (LFS) (less than $150 \mathrm{~mm}$ in 20 seconds) in the small flame ignitability test (ISO 11925-2). However, alongside the extensive series of interlaboratory reproducibility tests, undertaken to validate the SBI test for 24 construction products, the area of flame spread was recorded [17]. The products were tested in thicknesses normally used. Wood panels were $12 \mathrm{~mm}$ thick, while all insulation materials were $100 \mathrm{~mm}$ thick. The area behind the burner flame was measured as $0.35 \mathrm{~m}^{2}$ (16\% of exposed surface area: a burn area per $\mathrm{m}^{2}$, or fractional burn area, $\left.\mathrm{b}^{\prime \prime}=0.16\right)$. For Euroclasses $\mathrm{A} 2, \mathrm{~B}$ and $\mathrm{C}$, no flame spread was observed beyond the area of the propane flame. Therefore, the burn area for these products may be taken as $0.35 \mathrm{~m}^{2}$. For Euroclass $\mathrm{D}$ products, the burn area was around $0.6 \mathrm{~m}^{2}$, corresponding to flames spreading upwards to the top of the specimen, but tapering as they neared the top, equal to $27 \%$ of total exposed specimen area; for Euroclass E products, the flame broadened as it spread upwards, giving a total burn area around $1.0 \mathrm{~m}^{2}$, corresponding to $44 \%$ of the total area (or a burn area per $\left.\mathrm{m}^{2}, \mathrm{~b}^{\prime \prime}=0.44\right)$. Euroclass $\mathrm{F}$ products do not have to meet any criteria and have been assumed to burn completely $\left(b^{\prime \prime}=1.0\right)$. The burn areas above relate to the scenario of the SBI test. If the test panels had a greater area, but the burner was the same size, the burn area b" would be smaller. If the SBI test were scaled up or down (burner and test panels increasing in proportion) then b" would be unaffected.

For products with Euroclass $\mathrm{A} 1$ and $\mathrm{A} 2$, the heat of combustion must be tested as gross calorific potential (PCS), and be less than 2 and $4 \mathrm{~kJ} \mathrm{~g}^{-1}$, respectively). The heat of combustion of other 
construction products may be easily determined by bomb calorimetry ${ }^{18}$ (ISO 1716), microscale combustion calorimetry ${ }^{19}$ (MCC) (ASTM D 7309 - method B) or cone calorimetry ${ }^{20}$ (ISO 5660) (as Effective Heat of Combustion), in units of $\mathrm{MJ} \mathrm{kg}^{-1}$, or $\mathrm{kJ} \mathrm{g}^{-1}$ with the same numerical value. For materials of low combustibility, particularly char formers and those with a small volatile fraction, $Y_{V}$, the burn thickness is likely to be significantly less than the sample thickness. For wood, known to have a penetrative burn rate of $0.6 \mathrm{~mm} \mathrm{~min}^{-1}$ at heat fluxes less than $100 \mathrm{~kW} \mathrm{~m}^{2}$ [21], the burn thickness in 10 minutes has been estimated as $6 \mathrm{~mm}$. For Euroclasses $A$ and $B$ a burn thickness of $50 \%$ has been assumed. For Euroclasses $C$ to $F, 100 \%$ burn thickness has been assumed. The burn thickness is related to the fractional burn thickness, $t_{b}$, by equation 4 .

$$
t_{b}=\frac{\text { Burn thickness }}{\text { Total thickness }}
$$

The burn area, burn thickness and density, all per unit area (indicated by ") allows a mass exposed per $\mathrm{m}^{2}$ of product, $m_{\mathrm{E}}$ " to be calculated, using equation 5 .

$$
m_{E} "=\rho^{\prime \prime} t_{b} b^{\prime \prime}
$$

The assumptions relating to burn thickness represent worst case scenarios, to be adopted in the absence of data from the SBI test. Where more precise information on particular materials is available from the SBI test results, such as burn area (the area showing damage to the surface), burn thickness (depth of damaged material $20 \mathrm{~cm}$ above the burner and $15 \mathrm{~cm}$ from the inside corner), and actual total heat release (THR), this will provide a more precise input to the model.

The combination of the heat of combustion, the burn depth and the Euroclass can be used to estimate the maximum mass loss per unit area $m_{L}$ " for non-layered products exposed to a fire, in a scenario corresponding to the SBI test (Equation 6).

$$
m_{L} "=\mathrm{m}_{\mathrm{E}} " Y_{V}=\rho^{\prime \prime} t_{b} b^{\prime \prime} Y_{V}
$$


Table 2 Example calculations of mass loss based on Euroclass and product data for samples of product of thickness $10 \mathrm{~cm}$.

\begin{tabular}{|c|c|c|c|c|c|c|c|c|c|c|}
\hline & \multicolumn{4}{|c|}{ Product Properties } & \multicolumn{6}{|c|}{ Estimated and Calculated Properties } \\
\hline Product type & $\begin{array}{l}\text { Euro- } \\
\text { class }\end{array}$ & $\begin{array}{l}\text { Euro- } \\
\text { class } \\
\text { criteria }\end{array}$ & $\begin{array}{c}\text { Area } \\
\text { density } \\
\rho^{\prime \prime}\end{array}$ & $\begin{array}{c}\text { Heat of } \\
\text { Combustion } \\
\Delta H_{c}\end{array}$ & $\begin{array}{l}\text { Burn } \\
\text { area } \\
b^{\prime \prime}\end{array}$ & $\begin{array}{c}\text { Fractional } \\
\text { burn } \\
\text { thickness } \\
t_{b}\end{array}$ & $\begin{array}{c}\text { Mass } \\
\text { exposed } \\
m_{\mathrm{E}}{ }^{\prime \prime}\end{array}$ & $\begin{array}{c}\text { Volatile } \\
\text { fraction } \\
Y_{v}\end{array}$ & $\begin{array}{l}\text { Mass } \\
\text { loss } \\
m\left\llcorner^{\prime \prime}\right.\end{array}$ & THR \\
\hline Units & & $\begin{array}{r}\text { /MJ (THR) } \\
\& \\
\mathrm{MJ} \mathrm{kg}^{-1} \\
(\mathrm{PCS}) \\
\end{array}$ & $/ \mathrm{kg} \mathrm{m}^{-2}$ & $/ \mathrm{MJ} \mathrm{kg}^{-1}$ & $/ \mathrm{m}^{2}$ & & $/ \mathrm{kg} \mathrm{m}^{-2}$ & - & $/ \mathrm{kg} \mathrm{m}^{-2}$ & /MJ \\
\hline Insulation 1 & A1 & $\mathrm{PCS}<2$ & 15 & 2 & 0.16 & 0.5 & 1.2 & 0.05 & 0.06 & 0.1 \\
\hline Insulation 2 & $\mathrm{~A} 2$ & $\begin{array}{r}\mathrm{THR}<7.5 \\
\mathrm{PCS}<4\end{array}$ & 10 & 4 & 0.16 & 0.5 & 0.8 & 0.1 & 0.08 & 0.3 \\
\hline Insulation 3 & B & THR $<7.5$ & 3.5 & 25 & 0.16 & 0.5 & 0.3 & 1 & 0.28 & 7.0 \\
\hline FR Wood & B & THR $<7.5$ & 60 & 20 & 0.16 & 0.04 & 0.4 & 1 & 0.38 & 7.7 \\
\hline Insulation 4 & $\mathrm{C}$ & THR $<15$ & 3 & 30 & 0.16 & 1 & 0.5 & 1 & 0.48 & 14.4 \\
\hline Insulation 5 & D & & 3.5 & 30 & 0.27 & 1 & 0.9 & 1 & 0.95 & 28.4 \\
\hline Non-FR Wood & $\mathrm{D}$ & & 50 & 20 & 0.27 & 0.06 & 0.8 & 1 & 0.81 & 16.2 \\
\hline Insulation 6 & $E$ & & 2 & 40 & 0.44 & 1 & 0.9 & 1 & 0.88 & 35.2 \\
\hline Insulation 7 & $\mathrm{~F}$ & & 2 & 40 & 1 & 1 & 2.0 & 1 & 2.00 & 80.0 \\
\hline
\end{tabular}


The volatile fraction can be determined from the material composition, or from the residue fraction in air at $900^{\circ} \mathrm{C}$. Examples of this mass loss calculation, covering the range of Euroclasses for typical insulation materials, and wood with and without fire retardant, as $10 \mathrm{~cm}$ thick sheet products, are shown in table 2 . The total heat release (THR) has also been calculated using literature values for heats of combustion, and meets the Euroclass criteria, to test the validity of the burn area and burn thickness assumptions, above using equation 7 .

$$
\text { THR }=m_{L} " \Delta H_{C}
$$

Table 3 shows estimates of the lethal volume of toxic fire effluent and maximum safe loadings of wall lining materials, using generic material- $\mathrm{LC}_{50}$ values reported elsewhere $[22,23,24]$, and the mass loss data described above. The lethal volume, $\mathrm{V}_{\mathrm{LC}}$, is calculated from the material- $\mathrm{LC}_{50}, \mathrm{~m}-\mathrm{LC}_{50}$, according to equation 8 .

$$
\mathrm{V}_{\mathrm{LC}_{50}}=\frac{m_{\mathrm{L}}{ }^{\prime \prime} \times 1000}{\mathrm{~m}-\mathrm{LC}_{50}}
$$

The burning behaviour from the SBI test has been assumed. In each case the material$\mathrm{LC}_{50}$ for the product burning in that fire condition is shown in $\mathrm{g} \mathrm{m}^{-3}$. This is the loading that would be lethal to $50 \%$ of the population, if they were exposed to that material burning under the specified condition. ISO 13571 [3] provides guidance that a precautionary factor of 3 would reduce the fatalities to just above $10 \%$, while a factor of 10 would reduce the fatalities to around $1 \%$ of the exposed population. For vulnerable or mobility impaired populations, larger factors are necessary. This allows a lethal volume and a maximum safe loading, $L_{s}$, ha to be calculated for each fire condition. This is shown in Table 3, using the factor of 10 for a healthy adult (ha) population, in equation 9 .

$$
\mathrm{L}_{\mathrm{s}, \mathrm{ha}}=\frac{100}{\mathrm{~V}_{\mathrm{LC}} \times 10}
$$

Two fire scenarios are described, well-ventilated and under-ventilated. However, the $\mathrm{SBI}$ is a well-ventilated test. In under-ventilated conditions the mass loss rate would be lower than in the SBI test. Conversely, the heat flux in the SBI test is only $40 \mathrm{~kW} \mathrm{~m}$ ${ }^{2}$ representing an early fire stage. In a developed fire the heat flux may exceed our 75 


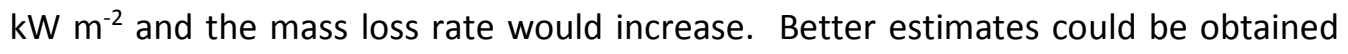
using more sophisticated modelling tools. The specific lethal volume of toxic effluent reported in Table 3 is that generated by burning a square metre of sheet product of thickness $10 \mathrm{~cm}$, in conditions equating to the SBI test. In addition, a "maximum safe loading" has also been calculated, using the precautionary factor of 3 , to ensure that the effluent is not lethal to most healthy occupants. This figure is based on the behaviour of young, healthy adults. This is the area of material that can safely be installed in a $100 \mathrm{~m}^{3}$ enclosure to ensure the fire effluent does not exceed toxic limits. The factor of 3 is described [3] in ISO 13571. An FED $=1$ is lethal to $50 \%$ of the population: an FED $=0.33 \%$ should allow $99 \%$ of the exposed population to survive Where the exposed population are likely to suffer any impairment, incapacitation or other obstacles to escape, this factor must be increased proportionately.

Table 3 Example toxicity calculations for generic materials of different Euroclass [22, 23, 24]

\begin{tabular}{|c|c|c|c|c|c|c|c|c|}
\hline & \multirow{2}{*}{$\begin{array}{l}\text { Indic- } \\
\text { ative } \\
\text { Euro- } \\
\text { class }\end{array}$} & \multirow[b]{2}{*}{$\begin{array}{l}\text { Mass } \\
\text { loss per } \\
\mathrm{m}^{2} \\
m^{\prime \prime} \\
/ \mathrm{kg} \mathrm{m}^{-2}\end{array}$} & \multicolumn{3}{|c|}{ Well-ventilated flaming } & \multicolumn{3}{|c|}{ Under-ventilated flaming } \\
\hline & & & $\begin{array}{l}\mathrm{LC}_{50} \\
\\
/ \mathrm{g} \mathrm{m}^{-3}\end{array}$ & $\begin{array}{l}\text { Lethal } \\
\text { volume } \\
\mathrm{V}_{\mathrm{LC}_{50}} \\
/ \mathrm{m}^{-3}\end{array}$ & $\begin{array}{l}\text { Maximum } \\
\text { safe } \\
\text { loading } \\
\mathrm{L}_{\mathrm{s}, \text { ha }} \\
/ \mathrm{m}^{2} \text { per } \\
100 \mathrm{~m}^{-3}\end{array}$ & $\begin{array}{l}\mathrm{LC}_{50} \\
/ \mathrm{g} \mathrm{m}^{-3}\end{array}$ & $\begin{array}{l}\text { Lethal } \\
\text { volume } \\
\mathrm{V}_{\mathrm{LC}_{50}} \\
/ \mathrm{m}^{3}\end{array}$ & $\begin{array}{l}\text { Maximum } \\
\text { safe } \\
\text { loading } \\
\mathrm{L}_{\mathrm{s}, \text { ha }} \\
/ \mathrm{m}^{2} \text { per } \\
100 \mathrm{~m}^{-3}\end{array}$ \\
\hline Insulation 1 & A1 & 0.06 & 175 & 0.3 & 29.17 & 175 & 0.3 & 29.17 \\
\hline Insulation 2 & $A 2$ & 0.08 & 125 & 0.6 & 15.63 & 125 & 0.6 & 15.63 \\
\hline Insulation 3 & B & 0.28 & 45 & 6.2 & 1.61 & 20 & 14.0 & 0.71 \\
\hline FR Wood & B & 0.38 & 100 & 3.8 & 2.60 & 25 & 15.4 & 0.65 \\
\hline Insulation 4 & C & 0.48 & 15 & 32.0 & 0.31 & 10 & 48.0 & 0.21 \\
\hline Insulation 5 & D & 0.95 & 15 & 63.0 & 0.16 & 10 & 94.5 & 0.11 \\
\hline Non-FR Wood & D & 0.81 & 100 & 8.1 & 1.23 & 25 & 32.4 & 0.31 \\
\hline Insulation 6 & $\mathrm{E}$ & 0.88 & 30 & 29.3 & 0.34 & 25 & 35.2 & 0.28 \\
\hline Insulation 7 & $\mathrm{~F}$ & 2.00 & 30 & 66.7 & 0.15 & 25 & 80.0 & 0.13 \\
\hline
\end{tabular}




\section{CONCLUSIONS}

Fires continue to drain society and the economy. Fire safety dominates every aspect of the built environment, from the position of buildings and their internal layout to the infrastructure that links them together. Although fire causes large property losses and relatively few deaths outside the domestic environment, quite rightly, the hazard to life still dominates our approach to fire safety. It is most surprising, therefore, to see the current complete disregard for regulating fire toxicity in the built environment within in Europe and the U.S. The fallacy of the argument that by focusing on ignitability, flame spread and heat release rate, fires can be avoided is demonstrated by the toll of deaths and serious injuries resulting from unwanted fires. The fact that the majority of these result from inhalation of toxic smoke underlines the need for proper regulation. The argument that fire toxicity is difficult to replicate on a benchscale does not stand up to the weight of peer-reviewed publications demonstrating the opposite.

This paper describes a simple approach for ensuring that buildings are not filled with sufficient combustible product that a fire can generate a toxic atmosphere, preventing escape and killing the occupants. The approach relies on easily obtained data using the steady state tube furnace (ISO TS 19700), heat of combustion data from either bomb calorimetry (which may be required, as PCS, for Euroclassification), MCC or cone calorimetry, and the data from the SBI test, (necessary to sell construction products for Euroclasses A2 to D within Europe). The method has been presented as simply as possible so that calculation can be undertaken on specific materials, following the methodology described. The results show large differences in the volume of toxic effluents, ranging from a safe loading of 29 square metres of the Euroclass A1 insulation material in a $100 \mathrm{~m}^{3}$ enclosure to 0.2 square metres of Euroclass $D$ Insulation material in the same $100 \mathrm{~m}^{3}$ enclosure, for well-ventilated flaming. For underventilated flaming, the differences are similar. $29 \mathrm{~m}^{2}$ of Euroclass A1 material may be safely installed in a $100 \mathrm{~m}^{3}$ enclosure, while only $0.1 \mathrm{~m}^{2}$ of Euroclass $D$ material may be safely installed in the same $100 \mathrm{~m}^{3}$ enclosure. Clearly, $0.1 \mathrm{~m}^{2}$ of $100 \mathrm{~mm}$ thick insulation material would not undergo under-ventilated burning in a $100 \mathrm{~m}^{3}$ enclosure, 
but if the effluent was released from a smaller volume (say $2 \mathrm{~m}^{3}$ ), it would present a toxic hazard in a $100 \mathrm{~m}^{3}$ enclosure. It is important to recognise that the data presented in this paper and the methodology provides a first approximation for estimation of the toxic fire hazard. It is not possible to make more generalised predictions about the actual rate of fire growth in specific scenarios based solely on the performance in the $\mathrm{SBI}$ test. There is greater uncertainty associated with the predictions from underventilated fires, which burn more slowly but with significantly larger toxic product yields. 


\section{REFERENCES}

1 Fire Statistics United Kingdom 2013-14; Department for Communities and Local Government: London, 2014, and preceding volumes.

2 ISO 13943:2008 Fire safety - Vocabulary.

3 ISO 13571:2012 Life-threatening components of fire - Guidelines for the estimation of time to compromised tenability in fires.

4 Regulation No 305/2011 of the European Parliament and of the Council: Harmonised conditions for the marketing of construction products. Official Journal of the European Union, March 2011.

5 ISO 9705:1993 Fire tests- Full-scale room test for surface products

6 EN 13823:2010 Reaction to fire tests for building products. Building products excluding floorings exposed to the thermal attack by a single burning item.

7 T R Hull, A A Stec, K Lebek, and D Price, Factors affecting the combustion toxicity of polymeric materials, Polymer Degradation and Stability, 92, 2239-2246, (2007).

8 ISO TS 19700:2007 Controlled equivalence ratio method for the determination of hazardous components of fire effluents.

9 ISO 12136:2011 Reaction to fire tests - Measurement of material properties using a fire propagation apparatus

10 Anna A. Stec and T. Richard Hull, Fire Toxicity Assessment: Comparison of Asphyxiant Yields from Laboratory and Large Scale Flaming Fires, Fire Safety Science, 11: 404-418, (2014).

11 Hull T.R., Quinn, R.E., Areri, I.G., and Purser, D.A., Combustion toxicity of fire retarded EVA, Polymer Degradation and Stability 77, 235-242, (2002).

12 A.A. Stec, K. Lebek, and T.R. Hull, Characterisation of the Steady State Tube Furnace (ISO TS 19700) for fire toxicity Assessment, Polymer Degradation and Stability, Vol. 93, p. 2058-2065, (2008).

13 A.A. Stec, K. Lebek, and T.R. Hull, Characterisation of the Steady State Tube Furnace (ISO TS 19700) for fire toxicity Assessment, Polymer Degradation and Stability, Vol. 93, p. 2058-2065, (2008).

14 Tewarson A., Heat release in fires, Fire and Materials, 4, 185-191, (1980).

15 Lyon R. E., Safronava N. and Stoliarov, S. I. The role of thermal decomposition kinetics in the burning of polymers, Interflam Proceedings, Interscience, UK, (2010).

16 EN 13501-1:2007 Fire classification of construction products and building elements. Classification using test data from reaction to fire tests.

17 Messerschmidt, B., Van Hees, P., Wickström, U., Prediction of SBI (single burning item) test results by means of cone calorimeter test results, Interflam Proceedings, Interscience, UK, (1999).

18 ISO 1716:2010 Reaction to fire tests for products - Determination of the gross heat of combustion (calorific value).

19 ASTM D7309 - 13 Standard Test Method for Determining Flammability Characteristics of Plastics and Other Solid Materials Using Microscale Combustion Calorimetry.

20 ISO 5660-1:2015 Reaction-to-fire tests - Heat release, smoke production and mass loss rate - Part 1: Heat release rate (cone calorimeter method) and smoke production rate (dynamic measurement).

21 Butler, C. P., Notes on charring rates in wood, Fire Research Note, No 896, 1971, UK.

22 Gann, R.G. et al, International Study of the Sublethal Effects of Fire Smoke on Survivability and Health (SEFS): Phase I Final Report, NIST Technical Note 1349. 
23 Stec, A.A., and Hull, T.R., Assessment of the fire toxicity of building insulation materials, Energy and Buildings, 43, 498-506, (2011).

24 Purser, D.A., Fardell, P.J., Rowley, J., Vollam, S., Bridgeman, B., and Ness, E. M., An improved tube furnace method for the generation and measurement of toxic combustion products under a wide range of fire conditions. Proceedings of the 6th International Conference Flame Retardants '94, London, UK (26-27 Jan 1994). Interscience Communications. 